Article

\title{
Effects of Diethyl Phosphate, a Non-Specific Metabolite of Organophosphorus Pesticides, on Serum Lipid, Hormones, Inflammation, and Gut Microbiota
}

\author{
Fangwei Yang ${ }^{1}$, Jinwang $\mathrm{Li}^{1}$, Guofang Pang ${ }^{1,2}$, Fazheng Ren ${ }^{1,3}$ and Bing Fang ${ }^{1, *(1)}$ \\ 1 Beijing Advanced Innovation Center for Food Nutrition and Human Health, College of Food Science and \\ Nutritional Engineering, China Agricultural University, Beijing 100083, China; fwyang@cau.edu.cn (F.Y.); \\ sdlijinwang@sina.com (J.L.); 519-02@cau.edu.cn (G.P.); renfazheng@cau.edu.cn (F.R.) \\ 2 Chinese Academy of Inspection and Quarantine, Beijing 100176, China \\ 3 Key Laboratory of Functional Dairy, Co-Constructed by Ministry of Education and Beijing Government, \\ and Beijing Laboratory of Food Quality and Safety, China Agricultural University, Beijing 100083, China \\ * Correspondence: bingfang@cau.edu.cn; Tel.: +86-10-62738589
}

Received: 2 May 2019; Accepted: 17 May 2019; Published: 24 May 2019

check for updates

\begin{abstract}
Organophosphorus pesticides (OPs) can be metabolized to diethyl phosphate (DEP) in the gut environment, which may affect the immune and endocrine systems and the microbiota. Correlations between OPs and diseases have been established by epidemiological studies, mainly based on the contents of their metabolites, including DEP, in the serum or urine. However, the effects of DEP require further study. Therefore, in this study, adult male rats were exposed to 0.08 or $0.13 \mathrm{mg} / \mathrm{kg}$ DEP for 20 weeks. Serum levels of hormones, lipids, and inflammatory cytokines as well as gut microbiota were measured. DEP significantly enriched opportunistic pathogens, including Paraprevotella, Parabacteroides, Alloprevotella, and Helicobacter, leading to a decrease in interleukin-6 (IL-6). Exposure to the high dose of DEP enriched the butyrate-producing genera, Alloprevotella and Intestinimonas, leading to an increase in estradiol and a resulting decrease in total triglycerides (TGs) and low-density lipoprotein cholesterol (LDL-C); meanwhile, DEP-induced increases in peptide tyrosine-tyrosine (PYY) and ghrelin were attributed to the enrichment of short-chain fatty acid-producing Clostridium sensu stricto 1 and Lactobacillus. These findings indicate that measuring the effects of DEP is not a proxy for measuring the effects of its parent compounds.
\end{abstract}

Keywords: endocrine system; hormones; inflammation; microbiome; DNA sequencing

\section{Introduction}

Organophosphorus pesticides (OPs) are frequently detected in food [1-3], and about 75\% of all registered OPs are metabolized in the body into measurable dialkyl phosphate metabolites, such as diethyl phosphate (DEP) [4]. Human biomonitoring of OP exposure could include the determination of these non-specific metabolites in urine [5-7]. Previously, epidemiological studies established correlations between OPs and endocrine system diseases [8-10] or infertility [11,12] based on urinary measurements of DEP. The endocrine-disrupting effects of OPs, including chlorpyrifos [13-18], diazinon [19,20], malathion [21], triazophos [22], and dimethoate [23], have only been proven in animal studies, which reported a disorder of hormones involved in the hypothalamic-pituitary-adrenal [20], hypothalamic-pituitary-thyroid [14,17-19], and hypothalamic-pituitary-gonadal axes [14-17,21-23]. All of these OPs metabolize to DEP in vivo; however, we do not know whether these effects are induced by the parent OPs or the metabolites, especially the non-specific metabolite, DEP. 
Ingested OPs are absorbed and metabolized in the gastrointestinal tract and subsequently interact with other organs and tissues due to the existence of enzymes that can metabolize OPs into DEP, including cytochrome P450 isoforms, carboxylesterase, and esterase paraoxonase-1 [24,25]. Therefore, the gut is the first system in the body to be exposed to and affected by pesticides and metabolites. As increasing evidence has emerged about the relationship between gut health and diseases [26,27], recent risk assessments of pesticides have begun to focus on the effects on gut endocrine cells [28], the gut barrier [29-31], gut inflammation [32,33], and gut microbiota [32,34-37]. Combined with the existence of DEP in foods [38], the gut is likely to be influenced by both the OPs and DEP. However, risk assessments of DEP are lacking, especially regarding the effects on gut microbiota and the endocrine system. Thus, in this study, we evaluated the effects of DEP on hormones and gut microbiota in an attempt to clarify whether it is appropriate to use DEP as a marker for OPs when assessing health risks.

\section{Results}

\subsection{Effects of DEP Exposure on Body Weight and Food Composition}

The mean body weight and food consumption of rats in each group during the experimental period are shown in Figure 1. DEP was given in equal molar doses to the 1/500 of the lethal dose 50 ( $\left.\mathrm{LD}_{50}\right)$ of two frequently detected pesticides, triazophos and chlorpyrifos, used in our previous studies, which led to endocrine-disrupting effects. Exposure to a low dose of DEP (DEP-L) did not affect the body weight of rats significantly ( $p>0.05)$; however, a high dose (DEP-H group) was associated with lower body weights compared with the control group, a factor that became significant after 20 weeks of exposure ( $p<0.05$, Figure 1A). No significant differences were found in regard to food consumption between groups $(p>0.05$, Figure 1B). Furthermore, DEP-induced inhibition of serum acetylcholinesterase (AChE) activity occurred (Figure 2), and DEP did not exhibit the same neurotoxicity as the OPs at the same molar dose (Figure S1).

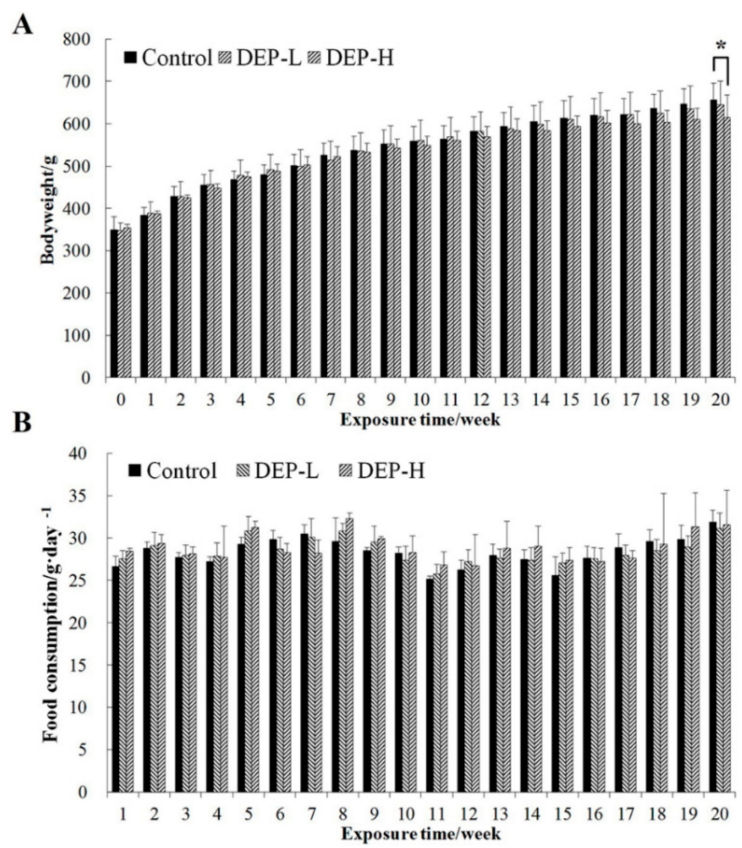

Figure 1. Body weight (A) and food consumption (B) of rats during the experimental period. Data are expressed as mean \pm standard deviation. Control, vehicle treatment; a low dose of diethyl phosphate (DEP-L), $0.08 \mathrm{mg} / \mathrm{kg}$ body weight; a high dose of diethyl phosphate (DEP-H), $0.13 \mathrm{mg} / \mathrm{kg}$ body weight. The symbol * indicates significant differences from the corresponding control group at the confidence interval of $95 \%$. 


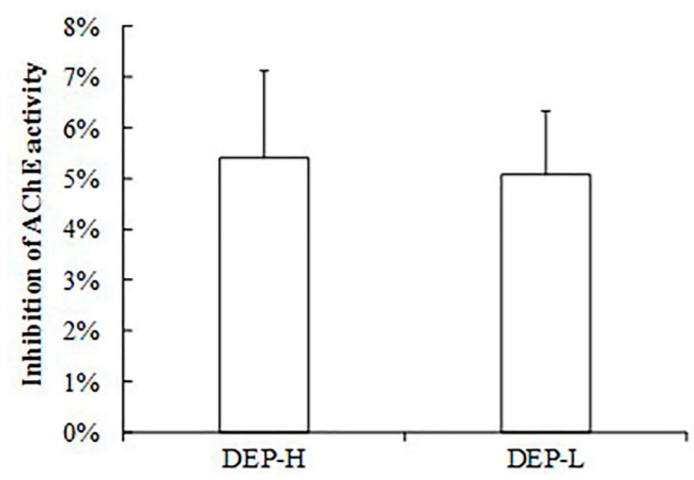

Figure 2. Inhibition in the activity of acetylcholin esterase (AChE) in the serum of rats exposed to DEP compared with the control group. The inhibition rate was calculated as the percentage of the activity value in DEP groups divided by the value in the control group.

\subsection{Effects of DEP Exposure on Serum Levels of Hormones and Lipids}

Serum levels of sex and adrenal hormones and lipids in rats exposed to DEP are shown in Figure 3. DEP exposure only increased the concentration of estradiol, leaving other hormones unchanged $(p>0.05$, Figure 3A,B). Meanwhile, DEP also significantly decreased the serum levels of total triglycerides (TGs) and low-density lipoprotein cholesterol (LDL-C) $(p<0.05$, Figure 3C).
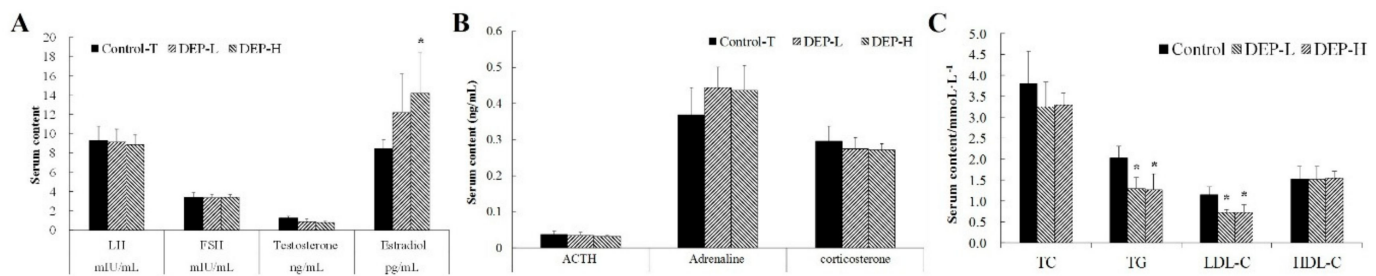

Figure 3. Serum levels of sex hormones (A) and adrenal hormones (B) and blood lipid profiles (C) in rats. The symbol * indicates significant differences from the corresponding control group at the confidence interval of 95\%. LH, luteinizing hormone; FSH, follicle-stimulating hormone; ACTH, adrenocorticotropic hormone; TC, total cholesterol; HDL-C, high density lipoprotein cholesterol.

\subsection{Effects of DEP on Gut Endocrine Cells and the Immune System}

The serum levels of gut hormones and inflammatory cytokines in rats exposed to DEP are shown in Figure 4. The serum concentrations of peptide tyrosine-tyrosine (PYY) and ghrelin increased significantly in the DEP-H group $(p<0.05$, Figure $4 \mathrm{~A})$. DEP exposure at both doses decreased the serum level of interleukin-6 (IL-6) significantly $(p<0.05$, Figure 4B).
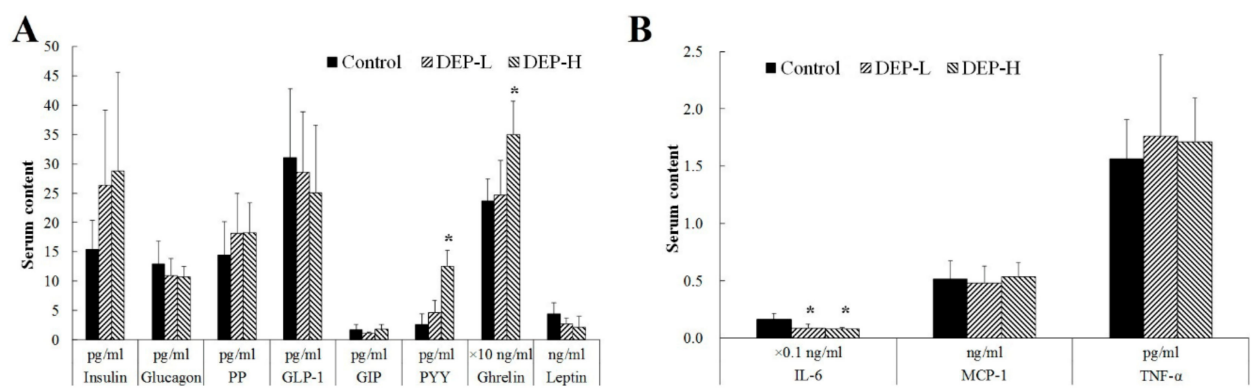

Figure 4. Serum levels of gut hormones (A) and inflammatory cytokines (B) in rats. The symbol * indicates significant differences from the corresponding control group at the confidence interval of 95\%. PP, pancreatic polypeptide; GLP-1, glucagon-like peptide 1; GIP, gastric inhibitory polypeptide; PYY, peptide tyrosine tyrosine; IL-6, interleukin 6; MCP-1, monocyte chemoattractant protein 1; TNF- $\alpha$, tumor necrosis factor alpha. 


\subsection{Effects of DEP on Gut Microbiota}

Figure 5 displays the principal coordinate analysis (PCoA) plots. The presence of significant differences in their relative abundance of genera between groups was analyzed using the Student's $t$-test. As shown in Figure 5A, there was less similarity in genera between DEP groups compared with between treatments and the control. Furthermore, the DEP-H group had less in common with the control group than the DEP-L group, which was in accordance with the idea that the genera composition was less altered in the DEP-L group (Figure 5C).

A

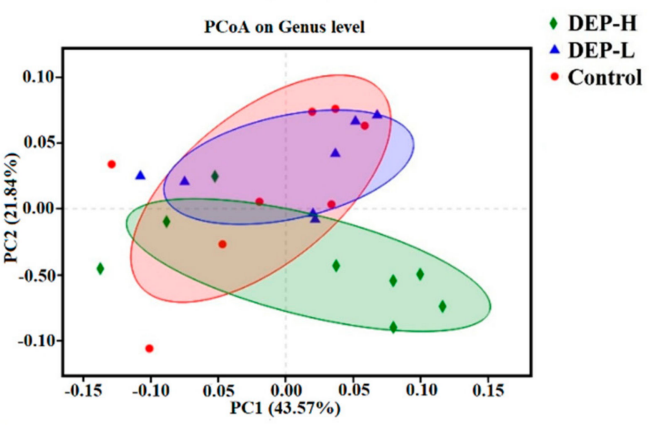

B

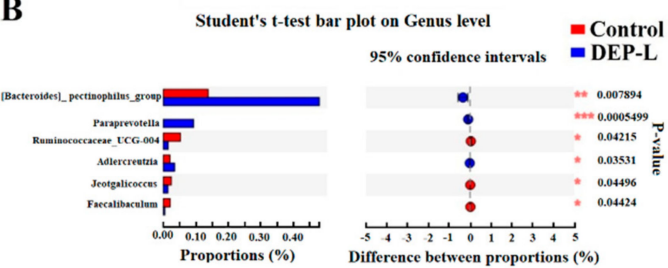

C

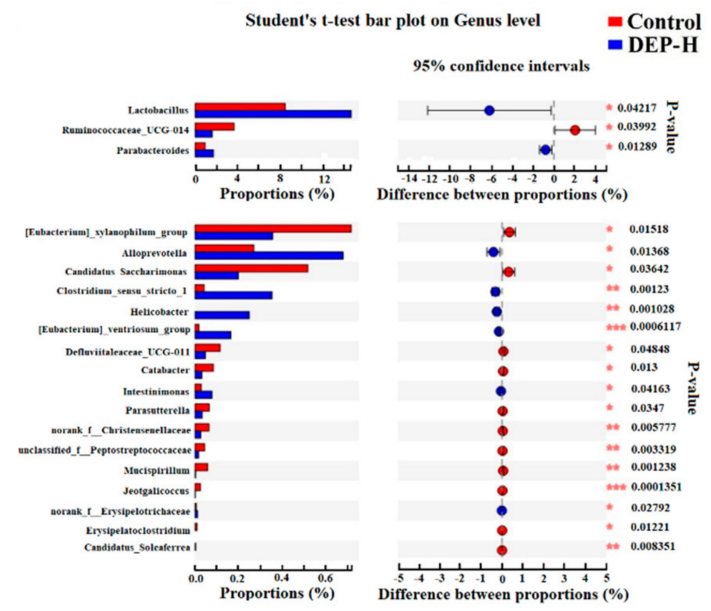

Figure 5. Altered gut microbiome community structure induced by DEP. (A) Principal coordinate analysis (PCoA) plots of gut microbiome patterns (circles, control; triangles, DEP-L; diamonds, DEP-H). The percentage of variation explained by the plotted principal coordinates is indicated on the axes. (B, C) Significantly altered genera analyzed by the Student's $t$-test in the DEP-L and DEP-H groups, respectively, compared with the control.

DEP-L exposure significantly enriched the relative abundance of the [Bacteroides] pectinophilus group, while Paraprevotella, and Adlercreutzia and depleted the concentrations of Ruminococcaceae_UCG-004, Jeotgalicoccus, and Faecalibaculum (Figure 5B, $p<0.05$ ). DEP-H increased the relative abundance of Lactobacillus, Parabacteroides, Alloprevotella, Clostridium sensu stricto 1, Helicobacter, [Eubacterium] ventriosum group, Intestinimonas, and norank $f$ Erysipelotrichaceae, whereas it depleted the concentrations of Jeotgalicoccus, Ruminococcaceae_UCG-014, [Eubacterium] xylanophilum group, Candidatus Saccharimonas, Defluviitaleaceae UCG-011, Catabacter, Parasutterella, norankf Christensenellaceae, unclassified $f$ Peptostreptococcaceae, Mucispirillum, Erysipelatoclostridium, and Candidatus Soleaferrea $(p<0.05$, Figure 5C).

\section{Discussion}

The levels of DEP in this study were based on the molar doses corresponding to the doses of triazophos and chlorpyrifos in our previous studies. Triazophos and chlorpyrifos are pesticides frequently detected in vegetables and fruits, and we evaluated the endocrine-disrupting effects of the two pesticides at the dose of 1/500 LD50 $(0.164 \mathrm{mg} / \mathrm{kg}$ b.w. and $0.3 \mathrm{mg} / \mathrm{kg}$ b.w. For triazophos and chlorpyrifos, respectively) [39,40]. Furthermore, the low dose of DEP $(0.08 \mathrm{mg} / \mathrm{kg} \mathrm{b} . \mathrm{w}$. $)$ in this study was also corresponded to the data in the urine of Chinese [41] after being transformed into rats with an average weight of $66.2 \mathrm{~kg}$ [42] and a urine volume of 2000 milliliters per day [43].

Previous epidemiologic studies established an association between OPs and disturbed hormone concentrations, especially reproductive hormones, based on urinary DEP measurements $[11,12,44]$. 
However, in accordance with Meeker et al. [45], this study could only provide evidence for an inverse relationship between DEP exposure and the serum level of estradiol (Figure 3A). Insufficient levels of estrogen in post-menopausal women have been shown to lead to an increase in plasma TG, and transdermal estradiol treatment can significantly lower plasma TG levels [46,47]. This effect has also been proven in adipocytes [48] and was reported to be the reason for decreased TC and LDL-C in estrogen-treated men [49], which is in accordance with the decreased serum levels of TG and LDL-C found in our study $(p<0.05$, Figure 3C). Evidence has also been found for the contribution of OPs to the development of obesity and diabetes, which may be due to the specific metabolites of OPs instead of the non-specific DEP.

Previous studies on the endocrine-disrupting mechanism of OPs focused on acetylcholine [50,51] and/or the interaction with hormone receptors [13,52]. In our study, no inhibitory effect of DEP on the activity of AChE was found (Figure 2), and the enriched Adlercreutzia in the DEP-L group was shown to be negatively correlated with anxiety behavior [53]. Adlercreutzia was also found to be depleted in patients with enteritis [54,55] and multiple sclerosis [56]; these results indicate the detoxification of OPs. However, when we continued to increase the dose of DEP, there were negative effects, such as significantly higher levels of estradiol (Figure $3 \mathrm{~A}, p<0.05$ ), PYY, and ghrelin (Figure $4 \mathrm{~A}, p<0.05$ ).

Gut health, determined by the function of gut endocrine and gut microbiota, influences the physiology and pathophysiology of the host [57]. Gut hormones, including ghrelin, PYY, GIP, GLP-1, and PP, are secreted by the intestinal epithelial cells [58] and communicate between the gut and the brain to affect the metabolism $[59,60]$ and behavior of the host $[61,62]$ by regulating the central nervous system and gut microbiota.

The alteration of gut microbiota, as well as their metabolites, such as short-chain fatty acids (SCFAs), has been reported to play a role in the regulation of the testis-pituitary axis [63] by disrupting steroid hormone synthesis [64]. It has been verified in cells that butyrate acid may increase the level of estradiol [65]. Accordingly, several butyrate-producing genera were significantly enriched in the DEP-H group, including Alloprevotella [66] and Intestinimonas [67] (Figure 5C, $p<0.05$ ). Furthermore, DEP-induced dysbiosis of gut microbiota also resulted in changes in gut hormones and inflammatory cytokines (Figure 4) $[58,68,69]$. SCFA-producing gut bacteria were also found to affect the secretion of PYY and ghrelin [70,71], and the enrichment in SCFA-producing Alloprevotella [66], Clostridium sensu stricto 1 [72], and Lactobacillus [73] may have been the reason for the significant increases in PYY and ghrelin in the DEP-H group (Figure $4 \mathrm{~A}, p<0.05$ ).

DEP exposure at both doses decreased the serum level of IL-6 significantly (Figure 4B, $p<$ $0.05)$, which is a pleiotropic cytokine implicated in acute phase responses and that controls antibody production from B lymphocytes [74]. The decreased IL-6 may be related to the significantly enriched opportunistic pathogens, including Paraprevotella [75,76], in the DEP-L group (Figure 5B, $p<0.05$ ) and Parabacteroides [75,77], Alloprevotella [77,78], and Helicobacter [79,80] in the DEP-H group (Figure 5C, $p<0.05)$. IL-6 is implicated in autoimmune and immunoinflammatory diseases such as SLE [81], rheumatoid arthritis [82], diabetes [83] and cancer [84]. It is necessary in future studies to aim at the mechanism of DEP in reducing IL- 6 while leaving TNF- $\alpha$ unchanged, which may help to design new inhibitors of IL-6. Furthermore, future studies may be of interest to evaluate the impact of DEP on other cytokines of the innate immune system such as IL-1, IL-12, IL-18 and IL-23.

In conclusion, chronic exposure to DEP, a non-specific metabolite of OPs, affected the gut microbiota, serum hormones, and proinflammatory cytokines in rats, with stronger responses observed at high doses. We speculate that the endocrine-disrupting effects of OPs depend more on their specific metabolites, but too much DEP would also disturb serum estradiol levels. These findings suggest that DEP is not a viable marker for precursor OPs when evaluating their toxicity on the endocrine system. 


\section{Materials and Methods}

\subsection{Animals and Experimental Design}

Seven-week-old male Wistar rats were purchased from the experimental animal center of Weitong Lihua Laboratory Animal Technology Company (Beijing, China). DEP (CAS 598-02-7) with a purity above 97\% was purchased from Huaxia Regent Company (Chengdu, China). Chemicals were dissolved in dimethyl sulfoxide (DMSO) and then diluted with $0.9 \%$ saline. The final DMSO concentration was $0.1 \%$. All procedures were performed humanely at China Agricultural University, following protocols approved by the university's ethics committee.

After a one-week acclimation period, rats were randomly divided into three groups $(n=10$ per group) to ensure minimal differences in bodyweight between groups. Rats from each group were housed in multiple cages to minimize the cage effect. DEP was administered by gavage once daily for 20 weeks at a dose of 0.08 (DEP-L) or $0.13 \mathrm{mg} / \mathrm{kg}$ (DEP-H) bodyweight. The administered doses were calculated on the basis of weekly weights. Rats in the control group were administrated with a vehicle of $0.9 \%$ saline containing $0.1 \%$ DMSO (control). The animals were given the same standard chow diet, and both feed and distilled water were available ad libitum. Throughout the experimental period, all rats were housed in cages and kept in a single room at $24 \pm 2{ }^{\circ} \mathrm{C}, 40 \%$ to $70 \%$ relative humidity, and a $12 \mathrm{~h}$ light/dark cycle. Bodyweight and food consumption were measured weekly throughout the experiment.

At the end of the exposure period, rats were anesthetized for blood collection from the orbit and decapitated. Plasma was centrifugated at $5000 \times \mathrm{g}$ for $20 \mathrm{~min}$ at $4{ }^{\circ} \mathrm{C}$ after standing for $2 \mathrm{~h}$ at $37^{\circ} \mathrm{C}$. The hemolyzed plasma was then discarded, and the upper layer of the serum was transferred to new sterile tubers and stored at $-80^{\circ} \mathrm{C}$ until further analysis.

\subsection{Fecal Sample Collection and Bacterial DNA Extraction}

Fecal samples were collected the day before sacrifice and later stored in sterile tubes containing RNA at $-20{ }^{\circ} \mathrm{C}$. Bacterial genomic DNA was extracted using the phenol-chloroform extraction method [85]. DNA was quantified using a NanoDrop spectrophotometer (OneC, Thermo Fisher Scientific, Waltham, MA, USA) and stored at $-80{ }^{\circ} \mathrm{C}$ until further analysis.

\subsection{AChE Activity Measurements}

Serum activity of AChE in rats at the end of exposure was determined spectrophotometrically using an AChE assay kit (Life Technologies, Carlsbad, CA, USA, Cat. No. \#A12217), according to the manufacturer's instructions. The inhibition rate was calculated from the activity value of the control subjects and represented as a percentage.

\subsection{Serum Lipid Profiles}

Serum levels of total cholesterol (TC), TG, LDL-C, and high-density lipoprotein cholesterol (HDL-C) were measured at the core laboratory of Peking University Third Hospital using an automatic biochemical analyzer.

\subsection{Hormones and Cytokine Measurements}

Serum levels of insulin, glucagon, pancreatic polypeptide (PP) (total), glucagon-like peptide 1 (GLP-1) (active), gastric inhibitory polypeptide (GIP) (total), PYY (total), ghrelin (active), leptin, IL-6, monocyte chemoattractant protein-1 (MCP-1), and tumor necrosis factor- $\alpha$ (TNF- $\alpha$ ) were quantified using a multiplexing kit (Milliplex MAP Rat Metabolic Hormone Magnetic Bead 13-Plex Panel, Catalog Number: MMHMAG-44K, RMHMAG-84K, Merck Millipore, Burlington, MA, USA) according to the manufacturer's protocol. Briefly, antibody beads were mixed together in a bottle and reagent solutions, which include standard, quality control, and blank solutions, were prepared according to the kit's 
guidelines. Samples and the standard quality controls were added into the well, then $200 \mu \mathrm{l}$ of the assay buffer was added. After shaking for $10 \mathrm{~min}$ at room temperature, $25 \mu \mathrm{l}$ of serum matrix solution and $25 \mu \mathrm{l}$ of mixed antibody beads were successively added to the background. The plate was sealed and incubated at $4{ }^{\circ} \mathrm{C}$ overnight, followed by washing three times with wash buffer. In total, $50 \mu \mathrm{l}$ of the detection antibodies were added and incubated for $30 \mathrm{~min}$ at room temperature on a plate shaker. Then, $50 \mu \mathrm{l}$ of streptavidin-phycoerythrin was added and incubated for $30 \mathrm{~min}$ at room temperature followed by the removal of all well contents and washing 3 times with the washing buffer. After that, $100 \mu \mathrm{l}$ of Luminex Sheath Fluid (which was used to drive the samples to the optic component of the Bio-plex machine) was added to each well before putting the plate inside the Bio-Plex machine to read the absorption.

Serum levels of luteinizing hormone (LH), follicle-stimulating hormone (FSH), adrenocorticotropic hormone (ACTH), testosterone, estradiol, adrenaline, and corticosterone were determined using the radioimmunoassay (RIA) method of Beijing Sino-UK Institute of Biological Technology (Beijing, China). Briefly, for measurement of serum LH, $50 \mu \mathrm{L}$ samples were assayed using a LH kit, following the manufacturer's instructions, and the assay sensitivity was $0.41 \mathrm{mIU} / \mathrm{mL}$. For measurement of serum FSH, $50 \mu \mathrm{L}$ samples were assayed using an FSH kit, which applies solid-phase RIA using an FSH-specific antibody immobilized to the wall of a polypropylene tube, and the assay sensitivity was $0.57 \mathrm{mIU} / \mathrm{mL}$. For measurement of serum ACTH, $100 \mu \mathrm{L}$ samples were assayed using an ACTH kit, which uses antibody-coated tubes. For measurement of serum testosterone and estradiol, $25 \mu \mathrm{L}$ samples were assayed using a total testosterone kit and a total estradiol kit, respectively, following the manufacturer's instructions, and the assay sensitivity was $0.15 \mathrm{ng} / \mathrm{mL}$ and $1.61 \mathrm{pg} / \mathrm{mL}$, respectively. For measurement of serum adrenaline, $25 \mu \mathrm{L}$ samples were assayed using an adrenaline kit, which applies solid-phase RIA using an adrenaline-specific antibody immobilized to the wall of a polypropylene tube. For measurement of serum total corticosterone, $50 \mu \mathrm{L}$ aliquots were assayed using a total corticosterone kit, following the manufacturer's instructions. In all analyses, the intra-assay coefficients of variation were below $10 \%$ and there were three parallel wells for each sample.

\subsubsection{S rRNA Gene Sequencing}

DNA was first amplified using the universal primers, B341 (5'-CCTACGGGNGGCWGCAG-3') and B785R ( $5^{\prime}$-GACTACHVGGGTATCTAATCC-3'), to target the V3 and V4 regions of bacterial 16S rRNA. PCR amplification was performed according to the protocol of the kit (KAPA Biosystems, Wilmington, MA, USA) with conditions as follows: Initial $95^{\circ} \mathrm{C}$ for $3 \mathrm{~min}$, followed by 25 cycles of $95^{\circ} \mathrm{C}$ for $30 \mathrm{~s}, 55^{\circ} \mathrm{C}$ for $30 \mathrm{~s}$, and $72{ }^{\circ} \mathrm{C}$ for $30 \mathrm{~s}$, and then a final extension of $72{ }^{\circ} \mathrm{C}$ for $5 \mathrm{~min}$. After purifying the positive amplicons using AMPure XP beads (AGENCOURT AMPURE XP Kit, Beckman Coulter Inc., Brea, CA, USA), the amplicons were assessed and quantified using a Qubit fluorometer (Thermo Fisher Scientific, San Jose, CA, USA) and KAPA Library Quantification Kit (KAPA Biosystems) according to the manufacturer's instructions. The resulting products were pooled and sequenced on an Illumina Miseq PE300 platform (Illumina, San Diego, CA, USA) using a paired-end sequencing strategy $(2 \times 300 \mathrm{bp})$. Raw data were spliced and filtered by removing the merged sequencing reads $\leq 200 \mathrm{bp}$ or $\geq 500 \mathrm{bp}$ in length and reads with a quality score of $\leq 20$ or those containing $\geq 4$ ambiguous base calls using MOTHUR software (version 1.35.1). The filtered and trimmed high-quality reads were then used to select the operational taxonomic units (OTUs) with USEARCH software (version 7.0) and a default cutoff of $97 \%$ sequence similarity. The OTUs were further subjected to the Ribosomal Database Project classifier software for taxonomic identification. An $80 \%$ confidence threshold was used for taxonomic assignment, and the taxonomic assignment was achieved at different levels, including phylum, class, order, family, and genus.

\subsection{Gut Microbiota Analysis}

$\beta$-diversity was assessed using weighted UniFrac distance matrices, which was the basis of PCoA and the abundance heatmap [86]. Differences in the composition of gut microbiota were further 
assessed by nonparametric tests using Metastats software [87]. Differences in the gut microbiome composition between the control and the DEP-treated group were further assessed by the Student's $t$-test using the FDR as the correction for multiple testing [88].

\subsection{Statistical Analysis}

For body weight and hematological indices (serum lipids, serum levels of hormones, and cytokines), data were expressed as mean \pm SD and analyzed using one-way ANOVA, followed by the Duncan's multiple range test at a 95\% confidence interval (SPSS version 19.0, IBM SPSS, Armonk, NY, USA).

Supplementary Materials: Supplementary Figure S1. Inhibition in the activity of AChE in the serum of rats exposed to DEP and OPs at the same molar doses compared with the control group. The inhibition rate was calculated as the percentage of the activity value in treated groups divided by the value in the control group.

Author Contributions: Conceptualization, G.P., F.R. and B.F.; Data curation, G.P., F.R. and B.F.; Formal analysis, F.Y., J.L. and B.F.; Investigation, F.Y. and J.L.; Methodology, F.Y. and J.L.; Supervision, G.P., F.R. and B.F.; Writing — original draft, F.Y., and B.F.; Writing — review and editing, G.P., F.R. and B.F.

Funding: This work was financially supported by the National Key Research \& Development Program of China (2017YFC1601803) and a Beijing Municipal Science and Technology Commission project (D171100008017003).

Conflicts of Interest: The authors declare no conflicts of interest.

\section{References}

1. USDA (United States Department of Agriculture). Pesticide Data Program: Annual summary, calendar year 2011. Available online: http://www.ams.usda.gov/AMSv1.0/getfile?dDocName=stelprdc5102692 (accessed on 3 October 2018).

2. PRiF (Expert Committee on Pesticide Residues in Food). Pesticide residues monitoring programme for quarter 1 2013. Available online: http://www.pesticides.gov.uk/Resources/CRD/PRiF/Documents/Results\% 20and\%20Reports/2013/2013\%20Q1\%20Final.pdf. (accessed on 3 December 2013).

3. FSANZ (Food Standards Australia New Zealand). The 23rd Australian Total Diet Survey. Available online: http://www.foodstandards.gov.au/publications/pages/23rdaustraliantotald5367.aspx (accessed on 18 December 2013).

4. Jain, R.B.; Consultant, P.; Georgia, D. Levels of dialkylphosphate metabolites in urine among general U.S. population. Environ. Toxicol. Pharmacol. 2016, 43, 74-82. [CrossRef]

5. Sudakin, D.L.; Stone, D.L. Dialkyl phosphates as biomarkers of organophosphates: The current divide between epidemiology and clinical toxicology. Clin. Toxicol. 2011, 49, 771-781. [CrossRef] [PubMed]

6. Berman, T.; Goldsmith, R.; Göen, T.; Spungen, J.; Novack, L.; Levine, H.; Amitai, Y.; Shohat, T.; Grotto, I. Urinary concentrations of organophosphate pesticide metabolites in adults in Israel: Demographic and dietary predictors. Environ. Int. 2013, 60, 183-189. [CrossRef] [PubMed]

7. Berman, T.; Göen, T.; Novack, L.; Beacher, L; Grinshpan, L.; Segev, D.; Tordjman, K. Urinary concentrations of organophosphate and carbamate pesticides in residents of a vegetarian community. Environ. Int. 2016, 96, 34-40. [CrossRef] [PubMed]

8. Hodgson, E.; Rose, R.L. Organophosphorus Chemicals: Potent Inhibitors of the Human Metabolism of Steroid Hormones and Xenobiotics. Drug Metab. Rev. 2006, 38, 149-162. [CrossRef] [PubMed]

9. Koutros, S. 389 Risk of total and aggressive prostate cancer and pesticide use in the Agricultural Health Study. Occup. Environ. Med. 2013, 70, 59-74. [CrossRef]

10. Evangelou, E.; Ntritsos, G.; Chondrogiorgi, M.; Kavvoura, F.K.; Hernández, A.F.; Ntzani, E.E.; Tzoulaki, I. Exposure to pesticides and diabetes: A systematic review and meta-analysis. Environ. Int. 2016, 91, 60-68. [CrossRef]

11. Miranda-Contreras, L.; Gómez-Pérez, R.; Rojas, G.; Cruz, I.; Berrueta, L.; Salmen, S.; Colmenares, M.; Barreto, S.; Balza, A.; Zavala, L.; et al. Occupational Exposure to Organophosphate and Carbamate Pesticides Affects Sperm Chromatin Integrity and Reproductive Hormone Levels among Venezuelan Farm Workers. J. Occup. Heal. 2013, 55, 195-203. [CrossRef] [PubMed]

12. Aguilar-Garduno, C.; Lacasana, M.; Blanco-Munoz, J.; Rodriguez-Barranco, M.; Hernandez, A.F.; Bassol, S.; Gonzalez-Alzaga, B.; Cebrian, M.E. Changes in male hormone profile after occupational organophosphate exposure. A longitudinal study. Toxicology 2013, 307, 55-65. [PubMed] 
13. Ghisari, M.; Long, M.; Tabbo, A.; Bonefeld-Jørgensen, E.C. Effects of currently used pesticides and their mixtures on the function of thyroid hormone and aryl hydrocarbon receptor in cell culture. Toxicol. Appl. Pharmacol. 2015, 284, 292-303.

14. Chebab, S.; Mekircha, F.; Leghouchi, E. Potential protective effect of Pistacia lentiscus oil against chlorpyrifos-induced hormonal changes and oxidative damage in ovaries and thyroid of female rats. Biomed. Pharmacother. 2017, 96, 1310-1316. [CrossRef]

15. Adedara, I.A.; Owoeye, O.; Ajayi, B.O.; Awogbindin, I.O.; Rocha, J.B.; Farombi, E.O. Diphenyl diselenide abrogates chlorpyrifos-induced hypothalamic-pituitary-testicular axis impairment in rats. Biochem. Biophys. Commun. 2018, 503, 171-176. [CrossRef]

16. Peiris, D.C.; Dhanushka, T. Low doses of chlorpyrifos interfere with spermatogenesis of rats through reduction of sex hormones. Environ. Sci. Pollut. 2017, 24, 20859-20867. [CrossRef] [PubMed]

17. Mosbah, R.; Yousef, M.I.; Maranghi, F.; Mantovani, A. Protective role of Nigella sativa oil against reproductive toxicity, hormonal alterations, and oxidative damage induced by chlorpyrifos in male rats. Toxicol Ind. Health 2016, 32, 1266-1277. [CrossRef] [PubMed]

18. Akande, M.G.; Shittu, M.; Uchendu, C.; Yaqub, L.S. Taurine ameliorated thyroid function in rats co-administered with chlorpyrifos and lead. Vet. Res. Commun. 2016, 40, 123-129. [CrossRef]

19. Ahmad, S.N.; Nasir, M.; Naureen, A.; Andleeb, S.; Raees, K.; Abbas, T.; Younis, A.; Ahmad, K.R. Histopathological and micrometric studies of diazinon exposure on thyroid and parathyroid tissues in mice. Biologia (Pakistan) 2018, 64, 10.

20. Raees, K.; Ishfaq, R.; Ullah, A.; Tahir, M.Z.; Abbas, T.; Tahir, H.M.; Mukhtar, M.K.; Arshad, M.; Khan, S.Y.; Ahmad, K.R. Histological and micrometric effects of diazinon exposure on adrenal medulla and cortex in mice. J. Appl. 2012, 40, 267-272. [CrossRef]

21. Geng, X.; Shao, H.; Zhang, Z.; Ng, J.C.; Peng, C. Malathion-induced testicular toxicity is associated with spermatogenic apoptosis and alterations in testicular enzymes and hormone levels in male Wistar rats. Environ. Toxicol. Pharmacol. 2015, 39, 659-667. [CrossRef] [PubMed]

22. Sharma, D.; Sangha, G.K.; Khera, K.S. Triazophos-induced oxidative stress and histomorphological changes in ovary of female Wistar rats. Pestic. Biochem. Physiol. 2015, 117, 9-18. [CrossRef]

23. Jallouli, M.; Dhouib, I.E.B.; Lasram, M.; Gharbi, N.; El Fazaa, S. Disruption of steroidogenesis after dimethoate exposure and efficacy of $\mathrm{N}$-acetylcysteine in rats: An old drug with new approaches. Environ. Sci. Pollut. 2016, 23, 7975-7984. [CrossRef]

24. Leoni, C.; Balduzzi, M.; Buratti, F.M.; Testai, E. The contribution of human small intestine to chlorpyrifos biotransformation. Toxicol. Lett. 2012, 215, 42-48. [CrossRef]

25. Harishankar, M.K.; Sasikala, C.; Ramya, M. Efficiency of the intestinal bacteria in the degradation of the toxic pesticide, chlorpyrifos. 3 Biotech 2013, 3, 137-142. [CrossRef] [PubMed]

26. Zhang, Y.-J.; Li, S.; Gan, R.-Y.; Zhou, T.; Xu, D.-P.; Li, H.-B.; Sugumaran, M. Impacts of Gut Bacteria on Human Health and Diseases. Int. J. Mol. Sci. 2015, 16, 7493-7519. [CrossRef] [PubMed]

27. Marchesi, J.R.; Adams, D.H.; Fava, F.; Hermes, G.D.A.; Hirschfield, G.M.; Hold, G.; Quraishi, M.N.; Kinross, J.; Smidt, H.; Tuohy, K.M.; et al. The gut microbiota and host health: A new clinical frontier. Gut 2016, 65, 330-339. [CrossRef] [PubMed]

28. Fang, B.; Li, J.W.; Zhang, M.; Ren, F.Z.; Pang, G.F. Chronic chlorpyrifos exposure elicits diet-specific effects on metabolism and the gut microbiome in rats. Food Chem. Toxicol. 2018, 111, 144-152. [CrossRef] [PubMed]

29. Condette, C.J.; Khorsi-Cauet, H.; Morlière, P.; Zabijak, L.; Reygner, J.; Bach, V.; Gay-Quéheillard, J. Increased Gut Permeability and Bacterial Translocation after Chronic Chlorpyrifos Exposure in Rats. PLoS ONE 2014, 9, e102217. [CrossRef]

30. Li, W.; Ehrich, M. Transient alterations of the blood-brain barrier tight junction and receptor potential channel gene expression by chlorpyrifos. J. Appl. Toxicol. 2013, 33, 1187-1191. [CrossRef]

31. Vismaya; Rajini, P.S. Oral exposure to the organophosphorus insecticide, Monocrotophos induces intestinal dysfunction in rats. Food. Chem. Toxicol. 2014, 71, 236-243. [CrossRef] [PubMed]

32. Jin, C.; Zeng, Z.; Fu, Z.; Jin, Y. Oral imazalil exposure induces gut microbiota dysbiosis and colonic inflammation in mice. Chemosphere 2016, 160, 349-358. [CrossRef]

33. Jin, C.; Zeng, Z.; Fu, Z.; Jin, Y. Chronic exposure to endosulfan induces inflammation in murine colon via $\beta$-catenin expression and IL-6 production. Chemosphere 2016, 13, 842-849. 
34. Jin, Y.; Wu, S.; Zeng, Z.Y.; Fu, Z. Effects of environmental pollutants on gut microbiota. Environ. Pollut. 2017, 222, 1-9. [CrossRef]

35. Jin, Y.; Zeng, Z.; Wu, Y.; Zhang, S.; Fu, Z. Oral Exposure of Mice to Carbendazim Induces Hepatic Lipid Metabolism Disorder and Gut Microbiota Dysbiosis. Toxicol. Sci. 2015, 147, 116-126. [CrossRef]

36. Reygner, J.; Joly Condette, C.; Bruneau, A.; Delanaud, S.; Rhazi, L.; Depeint, F.; Abdennebi-Najar, L.; Bach, V.; Mayeur, C.; Khorsi-Cauet, H. Changes in Composition and Function of Human Intestinal Microbiota Exposed to Chlorpyrifos in Oil as Assessed by the SHIME ${ }^{\circledR}$ Model. Int. J. Environ. Res. Public Health 2016, 13, 1088. [CrossRef]

37. Velmurugan, G.; Ramprasath, T.; Swaminathan, K.; Mithieux, G.; Rajendhran, J.; Dhivakar, M.; Parthasarathy, A.; Babu, D.D.V.; Thumburaj, L.J.; Freddy, A.J.; et al. Gut microbial degradation of organophosphate insecticides-induces glucose intolerance via gluconeogenesis. Genome Biol. 2017, 18, 8. [CrossRef] [PubMed]

38. Zhang, X.; Driver, J.H.; Li, Y.; Ross, J.H.; Krieger, R.I. Dialkylphosphates (DAPs) in Fruits and Vegetables May Confound Biomonitoring in Organophosphorus Insecticide Exposure and Risk Assessment. J. Agric. Food Chem. 2008, 56, 10638-10645. [CrossRef] [PubMed]

39. Pesticide residues in food 2002 Joint FAO/WHO Meeting on Pesticide Residues TRIAZOPHOS. Available online: http://www.inchem.org/documents/jmpr/jmpmono/2002pr14.htm (accessed on 10 May 2019).

40. Wang, H.-P.; Liang, Y.-J.; Long, D.-X.; Chen, J.-X.; Hou, W.-Y.; Wu, Y.-J. Metabolic Profiles of Serum from Rats after Subchronic Exposure to Chlorpyrifos and Carbaryl. Chem. Toxicol. 2009, 22, 1026-1033. [CrossRef]

41. Fu, Y.; Xie, W. Analysis of exposure levels of several common environmental pollutants in medical examination population. J. Qiqihar Uni. Med. 2013, 34, 2897-2898. (In Chinese)

42. National Health Commission of the People's Republic of China. The Report on Nutrition and Chronic Diseases of Chinese Residents. Available online: http://www.nhc.gov.cn/jkj/s5879/201506/ 4505528e65f3460fb88685081ff158a2.shtml (accessed on 15 April 2019).

43. Urine 24-Hour Volume. Available online: https://medlineplus.gov/ency/article/003425.htm (accessed on 29 March 2019).

44. Omoike, O.E.; Lewis, R.C.; Meeker, J.D. Association between urinary biomarkers of exposure to organophosphate insecticides and serum reproductive hormones in men from NHANES 1999-2002. Reprod Toxicol 2015, 53, 99-104. [CrossRef] [PubMed]

45. Meeker, J.D.; Ravi, S.R.; Barr, D.B.; Hauser, R. Circulating estradiol in men is inversely related to urinary metabolites of nonpersistent insecticides. Reprod. Toxicol. 2008, 25, 184-191. [CrossRef] [PubMed]

46. Korljan, B.; Bagatin, J.; Kokić, S.; Matulić, N.B.; Ostojić, S.B.; Deković, A. The impact of hormone replacement therapy on metabolic syndrome components in perimenopausal women. Med. Hypotheses 2010, 74, 162-163. [CrossRef] [PubMed]

47. Whitcroft, S.I.; Crook, D.; Marsh, M.S.; Ellerington, M.C.; I Whitehead, M.; Stevenson, J.C. Long-term effects of oral and transdermal hormone replacement therapies on serum lipid and lipoprotein concentrations. Obstet. Gynecol. 1994, 84, 222-226.

48. Luo, F.; Huang, W.-Y.; Guo, Y.; Ruan, G.-Y.; Peng, R.; Li, X.-P. 17ß-estradiol lowers triglycerides in adipocytes via estrogen receptor $\alpha$ and it may be attenuated by inflammation. Lipids Heal. 2017, 16, 182. [CrossRef]

49. Filippatos, T.; Liberopoulos, E.; Pavlidis, N.; Elisaf, M.; Mikhailidis, D.; Filippatos, T.; Liberopoulos, E.; Elisaf, M. Effects of hormonal treatment on lipids in patients with cancer. N.a. Rev. 2009, 35, 175-184. [CrossRef] [PubMed]

50. Lecomte, M.J.; Bertolus, C.; Ramanantsoa, N.; Saurini, F.; Callebert, J.; Sénamaud-Beaufort, C.; Ringot, M.; Bourgeois, T.; Matrot, B.; Collet, C.; et al. Acetylcholine modulates the hormones of the growth hormone/insulin like growth factor-1 axis during development in mice. Endocrinology 2018, 159, 1844-1859. [CrossRef] [PubMed]

51. Yasuda, K.; Sumi, G.; Kanamori, C.; Nakajima, T.; Tsuzuki, T.; Cho, H.; Nishigaki, A.; Okada, H.; Kanzaki, H. Effects of ovarian hormone treatment on the gene expression of muscarinic acetylcholine receptors in the ovariectomized rat myometrium. J. Steroid Biochem. Mol. Boil. 2014, 143, 81-89. [CrossRef] [PubMed]

52. Pan, C.; Wang, Q.; Liu, Y.-P.; Xu, L.-F.; Li, Y.-F.; Hu, J.-X.; Jiang, M.; Zhang, J.-P.; Zhang, M.-R.; Yu, H.-M.; et al. Anti-androgen effects of the pyrethroid pesticide cypermethrin on interactions of androgen receptor with corepressors. Toxicology 2013, 311, 178-183. [CrossRef] 
53. Xu, Z.; Wang, C.; Dong, X.; Hu, T.; Wang, L.; Zhao, W.; Zhu, S.; Li, G.; Hu, Y.; Gao, Q.; et al. Chronic alcohol exposure induced gut microbiota dysbiosis and its correlations with neuropsychic behaviors and brain BDNF/Gabra1 changes in mice. BioFactors 2018, 45, 187-199. [CrossRef]

54. Shaw, K.A.; Bertha, M.; Hofmekler, T.; Chopra, P.; Vatanen, T.; Srivatsa, A.; Prince, J.; Kumar, A.; Sauer, C.; Zwick, M.E.; et al. Dysbiosis, inflammation, and response to treatment: A longitudinal study of pediatric subjects with newly diagnosed inflammatory bowel disease. Genome Med. 2016, 8, 75. [CrossRef]

55. Bajer, L.; Kverka, M.; Kostovcik, M.; Macinga, P.; Dvorak, J.; Stehlikova, Z.; Brezina, J.; Wohl, P.; Spicak, J.; Drastich, P. Distinct gut microbiota profiles in patients with primary sclerosing cholangitis and ulcerative colitis. World J. Gastroenterol. 2017, 23, 4548-4558. [CrossRef] [PubMed]

56. Chen, J.; Chia, N.; Kalari, K.R.; Yao, J.Z.; Novotna, M.; Soldan, M.M.P.; Luckey, D.H.; Marietta, E.V.; Jeraldo, P.R.; Chen, X.; et al. Multiple sclerosis patients have a distinct gut microbiota compared to healthy controls. Sci. Rep. 2016, 6, 28484. [CrossRef]

57. Peterson, L.W.; Artis, D. Intestinal epithelial cells: Regulators of barrier function and immune homeostasis. Nat. Rev. Immunol. 2014, 14, 141-153. [CrossRef]

58. Alonso, C.; Vicario, M.; Pigrau, M.; Lobo, B.; Santos, J.; Pastor, M.P. Intestinal Barrier Function and the Brain-Gut Axis. Purine and Pyrimidine Metabolism in Man V 2014, 817, 73-113.

59. Heni, M.; Kullmann, S.; Gallwitz, B.; Haring, H.-U.; Preissl, H.; Fritsche, A. Dissociation of GLP-1 and insulin association with food processing in the brain: GLP-1 sensitivity despite insulin resistance in obese humans. Mol. Metab. 2015, 4, 971-976. [CrossRef]

60. Lee, Y.-S.; Jun, H.-S. Anti-diabetic actions of glucagon-like peptide-1 on pancreatic beta-cells. Metab. Clin. Exp. 2014, 63, 9-19. [CrossRef] [PubMed]

61. Shi, L.M.; Du, X.X.; Jiang, H.; Xie, J.X. Ghrelin and Neurodegenerative Disorders-a Review. Mol. Neurobiol. 2017, 54, 1144-1155. [CrossRef]

62. Stadlbauer, U.; Woods, S.C.; Langhans, W.; Meyer, U. PYY3-36: Beyond food intake. Front. Neuroendocrinol. 2015, 38, 1-11. [CrossRef] [PubMed]

63. Al-Asmakh, M.; Stukenborg, J.-B.; Reda, A.; Anuar, F.; Strand, M.-L.; Hedin, L.; Pettersson, S.; Söder, O. The Gut Microbiota and Developmental Programming of the Testis in Mice. PLoS ONE 2014, 9, 103809. [CrossRef]

64. Gérard, P. Gastrointestinal Tract: Microbial Metabolism of Steroids. In Handbook of Hydrocarbon and Lipid Microbiology; Springer Nature: Basingstoke, UK, 2010; pp. 3133-3140.

65. Lu, N.; Li, M.; Lei, H.; Jiang, X.; Tu, W.; Lu, Y.; Xia, D. Butyric acid regulates progesterone and estradiol secretion via cAMP signaling pathway in porcine granulosa cells. J. Steroid Biochem. Mol. Boil. 2017, 172, 89-97. [CrossRef] [PubMed]

66. Liu, J.; Yue, S.; Yang, Z.; Feng, W.; Meng, X.; Wang, A.; Peng, C.; Wang, C.; Yan, D.; Yan, Z. Oral hydroxysafflor yellow A reduces obesity in mice by modulating the gut microbiota and serum metabolism. Pharmacol. Res. 2018, 134, 40-50. [CrossRef]

67. Shetty, S.A.; Lagkouvardos, I.; Ritari, J.; Chamlagain, B.; Douillard, F.P.; Paulin, L.; Piironen, V.; Clavel, T.; Plugge, C.M.; De Vos, W.M.; et al. Comparative genomics and physiology of the butyrate-producing bacterium Intestinimonas butyriciproducens. Environ. Microbiol. Rep. 2016, 8, 1024-1037.

68. Palm, N.W.; De Zoete, M.R.; Flavell, R.A. Immune-microbiota interactions in health and disease. Clin. Immunol. 2015, 159, 122-127. [CrossRef]

69. Lyte, M. Microbial Endocrinology in the Microbiome-Gut-Brain Axis: How Bacterial Production and Utilization of Neurochemicals Influence Behavior. PLOS Pathog. 2013, 9, e1003726. [CrossRef] [PubMed]

70. Psichas, A.; Sleeth, M.L.; Murphy, K.G.; Brooks, L.; Bewick, G.A.; Hanyaloglu, A.C.; Ghatei, M.A.; Bloom, S.R.; Frost, G. The short chain fatty acid propionate stimulates GLP-1 and PYY secretion via free fatty acid receptor 2 in rodents. Int. J. Obes. 2015, 39, 424-429. [CrossRef]

71. Chambers, E.S.; Morrison, D.J.; Frost, G. Control of appetite and energy intake by SCFA: What are the potential underlying mechanisms? Proc. Nutr. Soc. 2015, 74, 328-336. [CrossRef]

72. Marathe, N.P.; Ranade, D.R.; Shouche, Y.S.; Lanjekar, V.B. Clostridium punense sp. nov. an obligate anaerobic bacteria isolated from healthy human faeces. Int. J. Syst. Evol. Microbiol. 2015, 65, 4749-4756. 
73. Lesniewska, V.; Rowland, I.; Cani, P.D.; Neyrinck, A.M.; Delzenne, N.M.; Naughton, P.J. Effect on Components of the Intestinal Microflora and Plasma Neuropeptide Levels of Feeding Lactobacillus delbrueckii, Bifidobacterium lactis, and Inulin to Adult and Elderly Rats. Appl. Environ. Microbiol. 2006, 72, 6533-6538. [CrossRef]

74. Tanaka, T.; Narazaki, M.; Masuda, K.; Kishimoto, T. Regulation of IL-6 in Immunity and Diseases. Purine Pyrimidine Metab. Man V 2016, 941, 79-88.

75. Ye, Z.; Zhang, N.; Wu, C.; Zhang, X.; Wang, Q.; Huang, X.; Du, L.; Cao, Q.; Tang, J.; Zhou, C.; et al. A metagenomic study of the gut microbiome in Behcet's disease. Microbiome 2018, 6, 135. [CrossRef] [PubMed]

76. Lv, L.-X.; Fang, D.-Q.; Shi, D.; Chen, D.-Y.; Yan, R.; Zhu, Y.-X.; Chen, Y.-F.; Shao, L.; Guo, F.-F.; Wu, W.-R.; et al. Alterations and correlations of the gut microbiome, metabolism and immunity in patients with primary biliary cirrhosis. Environ. Microbiol. 2016, 18, 2272-2286. [CrossRef]

77. Kang, Y.; Li, Y.; Du, Y.; Guo, L.; Chen, M.; Huang, X.; Yang, F.; Hong, J.; Kong, X. Konjaku flour reduces obesity in mice by modulating the composition of the gut microbiota. Int. J. Obes. 2018, 1. [CrossRef]

78. Hu, Y.-L.; Pang, W.; Huang, Y.; Zhang, Y.; Zhang, C.-J. The Gastric Microbiome Is Perturbed in Advanced Gastric Adenocarcinoma Identified Through Shotgun Metagenomics. Front. Microbiol. 2018, 8, 433. [CrossRef]

79. Blosse, A.; Lehours, P.; Wilson, K.T.; Gobert, A.P. Helicobacter: Inflammation, immunology, and vaccines. Helicobacter 2018, 23, e12517. [CrossRef]

80. Wang, F.; Meng, W.; Wang, B.; Qiao, L. Helicobacter pylori-induced gastric inflammation and gastric cancer. Cancer Lett. 2014, 345, 196-202. [CrossRef]

81. Barcellini, W.; Rizzardi, G.; Borghi, M.; Nicoletti, F.; Fain, C.; Del Papa, N.; Meroni, P. In vitro type-1 and type-2 cytokine production in systemic lupus erythematosus: Lack of relationship with clinical disease activity. Lupus 1996, 5, 139-145. [CrossRef]

82. Hirano, D.; Nagashima, M.; Ogawa, R.; Yoshino, S. Serum levels of interleukin 6 and stress related substances indicate mental stress condition in patients with rheumatoid arthritis. J. Rheumatol. 2001, 28, 490-495.

83. Oh, Y.S.; Bae, G.D.; Park, E.-Y.; Jun, H.-S. MicroRNA-181c Inhibits Interleukin-6-mediated Beta Cell Apoptosis by Targeting TNF- $\alpha$ Expression. Molecules 2019, 24, 1410. [CrossRef] [PubMed]

84. Knüpfer, H.; Preiss, R. Serum interleukin-6 levels in colorectal cancer patients-A summary of published results. Int. J. Colorectal Dis. 2010, 25, 135-140. [CrossRef]

85. Köchl, S.; Niederstätter, H.; Parson, W. DNA extraction and quantitation of forensic samples using the phenol-chloroform method and real-time PCR. Methods Mol. Boil. (Clifton, N.J.) 2005, 297, 18.

86. Calderón, K.; Spor, A.; Breuil, M.C.; Bru, D.; Bizouard, F.; Violle, C.; Barnard, R.L.; Philippot, L. Effectiveness of ecological rescue for altered soil microbial communities and functions. ISME J. 2017, 11, 272. [CrossRef] [PubMed]

87. White, J.R.; Nagarajan, N.; Pop, M. Statistical Methods for Detecting Differentially Abundant Features in Clinical Metagenomic Samples. PLOS Comput. Boil. 2009, 5, e1000352. [CrossRef]

88. Zheng, J.; Xiao, X.-H.; Zhang, Q.; Mao, L.-L.; Yu, M.; Xu, J.-P.; Wang, T. Correlation of placental microbiota with fetal macrosomia and clinical characteristics in mothers and newborns. Oncotarget 2017, 8, 82314-82325. [CrossRef] [PubMed]

Sample Availability: Samples of the compounds are available from the authors. 